\title{
THE FORMATION AND FUNCTION OF THE CORPUS LUTEUM IN THE AFRICAN ELEPHANT, LOXODONTA AFRICANA
}

\author{
J. HANKS AND R. V. SHORT \\ Department of Veterinary Clinical Studies, Madingley Road, Cambridge
}

(Received 22nd fuly 1971, accepted 13th October 1971)

\begin{abstract}
Summary. The uterus and ovaries of 617 elephants shot in Zambia were examined. Corpora lutea seem to be necessary for the development of the endometrial glands, and before conception can occur, a certain critical mass of luteal tissue has to be achieved by accumulating crops of CL from successive oestrous cycles. The elephant can be either monovular or polyovular, and ovulation is spontaneous. New ovulations do not occur during pregnancy, and the presence of an embryo prolongs the life of the CL. There is great variability in luteal size, small cL being commonest in non-pregnant animals and large ones in pregnant animals. The GL do not enlarge during gestation, and some of the smaller ones may regress. The number of $\mathrm{CL}$ in pregnant elephants varied with the age of the cow, the younger elephants having a significantly higher number. Larger CL ( $>20 \mathrm{~mm}$ in diameter) predominated in older animals. Very little progesterone appears to be secreted by the corpora lutea, and the hormone could not be detected in the peripheral blood during gestation. If progesterone is necessary for pregnancy, the elephant must be extremely sensitive to it, and may be forced to accumulate a large mass of relatively inactive GL before sufficient hormone is available to enable the animal to become pregnant.
\end{abstract}

\section{INTRODUCTION}

The cL of the African elephant differ from those of other mammals in that they contain only minute quantities of progesterone (Short \& Buss, 1965; Short, 1966; Smith, Hanks \& Short, 1969), and it is uncertain whether they ever function as endocrine glands; for example, the presence of large CL in the ovaries does not prevent an animal coming into oestrus (Short, 1966). Although CL are present throughout the 22 months of pregnancy, there is an enormous variation both in their number and their size; some animals may have as many as forty-two, or as few as two, and the total mass of luteal tissue may vary from about 7 to $56 \mathrm{~g}$ (Laws, 1969). Various theories have been put forward to account for this; Perry (1953) regarded the elephant as polyovular and capable of accumulating GL during successive oestrous cycles. $\mathrm{He}$ also thought that the initial CL of pregnancy were replaced by a second set at 
about mid-gestation. Short (1966) studied one animal throughout oestrus and came to the conclusion that the elephant was monovular, but capable of accumulating cL from successive cycles until it eventually became pregnant. Buss \& Smith (1966) and Laws (1969) could find no evidence for the formation of new GL during pregnancy, and Laws concluded that the elephant was usually polyovular and had a number of cycles before becoming pregnant.

The purpose of this study was to establish whether the cL are truly functional by studying endometrial histology and blood progesterone levels at various stages of the cycle, and to explain why there is such a great variation in the size and number of the CL.

\section{MATERIALS AND METHODS}

From 1967 to 1969, ovaries were collected from 617 elephants killed in the Luangwa Valley, Zambia, as part of the Government's game cropping policy (Department of Wildlife, Fisheries and National Parks, 1969). The killing of elephants was limited to the dry months of the year, from May to November. Age was estimated from the degree of molar tooth wear (Laws, 1966). Ovaries were weighed when fresh, and preserved in $10 \%$ formalin. They were later cut into 3-mm slices, and the $\mathrm{CL}$, corpora albicantia (brown regressing $\mathrm{CL}$ ) and follicles were counted and measured. Luteal tissue weight was estimated from linear measurements by the equation of Laws (1969). Fetuses were weighed and the gestational age estimated from the data of Perry (1953). Uteri were examined macroscopically in non-pregnant individuals and the placental scars counted. The diameter of the uterine lumen in that part of the uterus where the horns are fused but where the right and left lumina are distinct was measured with calipers. A piece of the endometrium was collected for histological examination from elephants in various stages of the reproductive cycle. Selected CL and pieces of endometrium were dehydrated, embedded in paraffin wax, sectioned at $8 \mu \mathrm{m}$, and stained with Mayer's haematoxylin and eosin, for subsequent histological examination. In these elephants, 100 deep endometrial glands were randomly selected, and the diameters measured by means of a calibrated micrometer eyepiece.

Approximately 1 litre of blood was collected from five sexually mature female elephants, by cutting their throats with a spear within a few minutes of shooting. Clotting was prevented by the addition of heparin, and the blood was cooled on ice in an insulated box during transport to the base camp. It was centrifuged within $4 \mathrm{hr}$ of death and the plasma frozen and flown to Cambridge for the progesterone determinations. These were carried out by the gas chromatographic procedure of Schomberg, Coudert \& Short (1967).

\section{RESULTS}

\section{Gross uterine morphology and endometrial histology}

The macroscopic appearance of the uterus (size, tone and diameter of lumen) in elephants approaching puberty was similar to that of animals which were immediately postpubertal, and which had accumulated only a small 
amount of luteal tissue (Pl. 1, Fig. 1). But as the weight of luteal tissue increased, the uterus increased in size (Pl. 1, Fig. 2) and became more hyperaemic, and the diameter of the lumen enlarged from 5 to $15 \mathrm{~mm}$. A further increase in the weight of luteal tissue was associated with complete occlusion of the uterine lumen (see Table 1), and it remained like this for the first 3 months of gestation (see Pl. I, Fig. 3). Between $3 \frac{1}{2}$ and 4 months of gestation, the lumen opened again and there was a marked reduction in general uterine tone, which was clearly visible externally (Pl. 1, Fig. 4). The uterus of elephants in lactational anoestrus differed from that of prepubertal animals in its greater size, presence of one or more placental scars, and larger lumen (10 to $30 \mathrm{~mm}$ ).

\section{TABLE 1}

OVARIAN AND UTERINE MORPHOLOGY OF THE SEVEN ELEPHANTS IN TEXT-FIG. 1 WITH GORPORA LUTEA BUT NO MAGROSGOPICALLY VISIBLE EMBRYOS

\begin{tabular}{|c|c|c|c|c|}
\hline $\begin{array}{l}\text { Animal } \\
\text { no. }\end{array}$ & $\begin{array}{l}\text { Age } \\
\text { (years) }\end{array}$ & Diameter of $C L$ in $m m$ (No. of $C L)$ & $\begin{array}{l}\text { Total luteal } \\
\text { tissue weight } \\
\quad(\mathrm{g})\end{array}$ & Uterine morphology \\
\hline 10 & 14 & $\begin{array}{l}\mathrm{L} 16(1), 14(1) \\
\mathrm{R} 7(1)\end{array}$ & $3 \cdot 2$ & Uterine lumen $5 \mathrm{~mm}$ \\
\hline 11 & 18 & $\begin{array}{l}\text { L } 9(1), 6(2), 5(1) \\
\text { R } 26(1), 19(1), 8(1)\end{array}$ & $12 \cdot 4$ & Endometritis in both horns \\
\hline $12^{*}$ & 18 & $\begin{array}{l}\text { L } 24(1), 9(1) \dagger \\
\text { R } 18(1), 5(1)\end{array}$ & $9 \cdot 5$ & $\begin{array}{l}\text { Uterus hyperaemic and lumen } \\
\text { quite large }\end{array}$ \\
\hline 13 & 15 & $\begin{array}{l}\text { L } 22(1), 17(1), 15(1), 12(1) \dagger \\
\quad 11(1), 8(2), 4(1) \\
\text { R 12(1), 11(2) }\end{array}$ & $12 \cdot 8$ & $\begin{array}{l}\text { Uterus hyperaemic and uterine } \\
\text { lumen } 15 \mathrm{~mm}\end{array}$ \\
\hline 14 & 49 & $\begin{array}{l}\text { L 18(1), 12(2), } 11(1) \\
\text { R 20(1), 14(1), 10(1) }\end{array}$ & $9 \cdot 5$ & $\begin{array}{l}\text { Uterine lumen completely } \\
\text { occluded }\end{array}$ \\
\hline 15 & 16 & $\begin{array}{l}\text { L } 33(1), 23(2), 16(1), 7(2) \\
\text { R } 8(1), 6(1), 3(1)\end{array}$ & 31.5 & $\begin{array}{l}\text { Uterine lumen completely } \\
\text { occluded }\end{array}$ \\
\hline 16 & 20 & $\begin{array}{l}\mathrm{L} 27(2), 18(1), 13(1), 5(1) \\
\mathrm{R} 0\end{array}$ & $22 \cdot 6$ & Uterine lumen $15 \mathrm{~mm}$ \\
\hline
\end{tabular}

* Already described by Short (1966).

$\uparrow$ Very recent ovulation. Confirmed histologically.

The size, number and degree of coiling of the deep endometrial glands varied during the reproductive cycle (see Text-fig. 1). Whilst there was no significant difference between prepubertal animals and those in lactational anoestrus, the diameter of the glands and their number per unit area showed a progressive increase as CL accumulated in the non-pregnant animals. Animals No. 15 and No. 16 which had the highest luteal tissue weight (see Table 1) also had the greatest development of their endometrial glands, which were similar in appearance to those of elephant No. 17, which had only just conceived. These three animals also showed the greatest degree of development of the endometrial crypts (see Plate 2). By the 3rd month of pregnancy (elephant No. 18), there had been a considerable reduction in the size and number of the endometrial glands.

Since the degree of glandular development seems to be related to the number of $\mathrm{CL}$, this is circumstantial evidence that the $\mathrm{CL}$ are functional, and apparently 
need to accumulate in the ovaries before maximal endometrial stimulation occurs.

\section{The corpus luteum}

The cropped sample included 320 postpubertal female elephants, of which 171 were pregnant, 117 were in lactational anoestrus and thirty-two had CL but were not pregnant. The greatest number of CL in a non-pregnant elephant

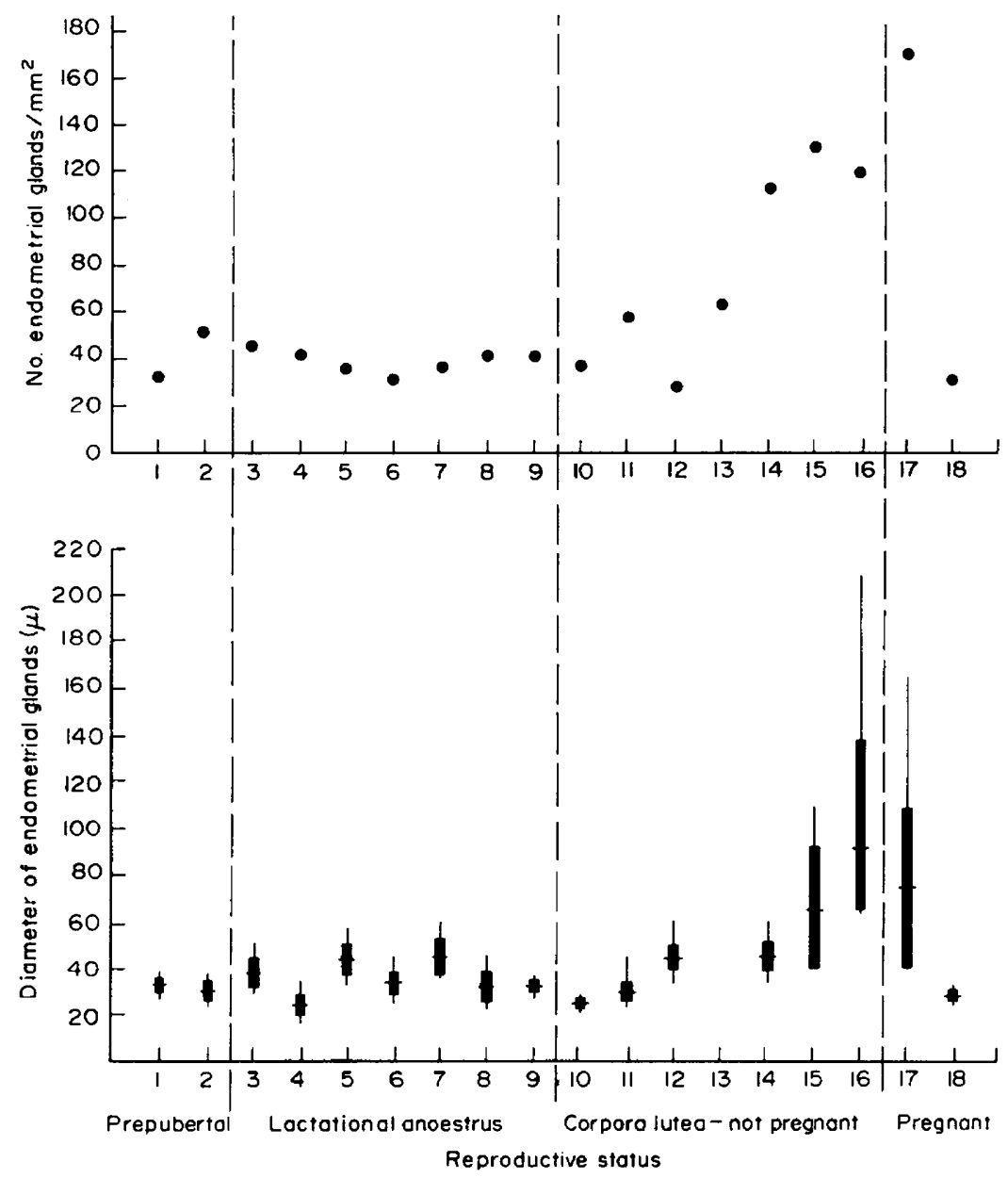

TEXT-FIG. 1. Size (range, mean and standard deviation) and number of deep endometrial glands in relation to the reproductive status of the African elephant.

was sixteen; one non-pregnant animal had only a single cL (see Text-fig. 2), and two other non-pregnant animals that had just ovulated had only a single fresh ovulation, confirming that on occasions elephants are monovular. Plate 3 illustrates the disparity in the size of CL in pregnant and non-pregnant elephants. During pregnancy, the number of cL ranged from two to twenty-six (see Textfig. 3 ), and the younger animals (see Table 2) had significantly more than the 
TABLE 2

VARIATIONS IN MEAN NUMBER OF GORPORA LUTEA WITH AGE IN PREGNANT ELEPHANTS

\begin{tabular}{c|c|c}
\hline $\begin{array}{c}\text { Age group } \\
\text { (years) }\end{array}$ & $\begin{array}{c}\text { No. of } \\
\text { elephants }\end{array}$ & Mean no. of CL/elephant \pm S.E.M. \\
\hline 13 to 22 & 50 & $7 \cdot 50 \pm 0.76$ \\
23 to 32 & 66 & $5 \cdot 24 \pm 0.38$ \\
33 to 42 & 31 & $5.38 \pm 0.53$ \\
43 to 60 & 24 & $4.96 \pm 0.52$ \\
\hline
\end{tabular}

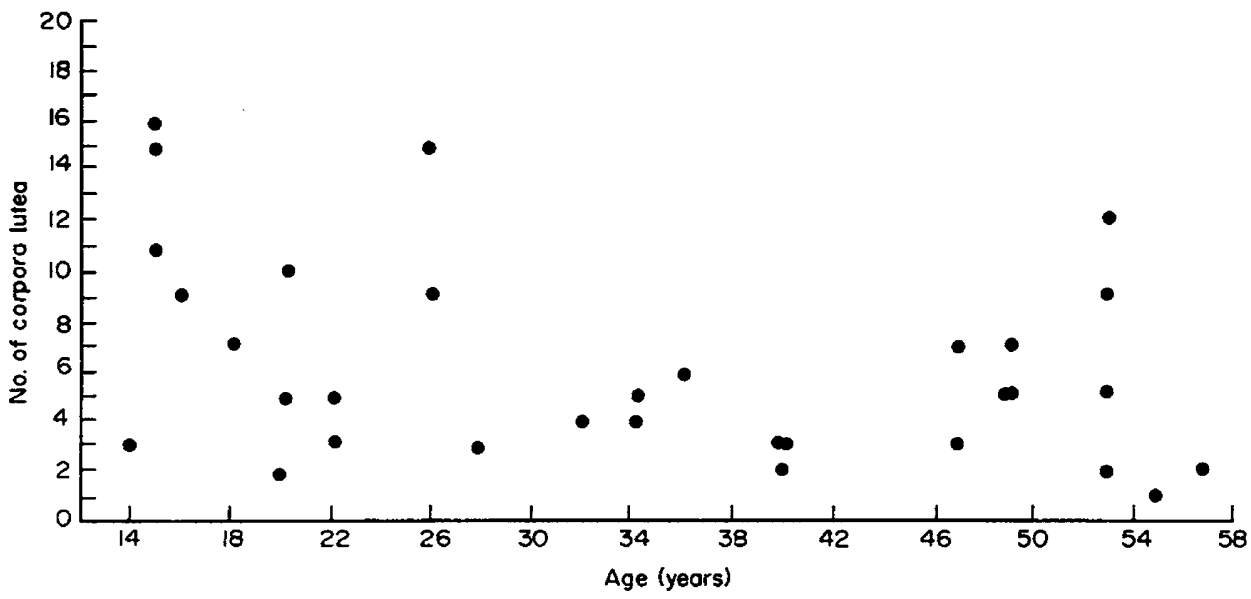

TExT-PIG. 2. Number of GL in non-pregnant elephants in relation to their age.

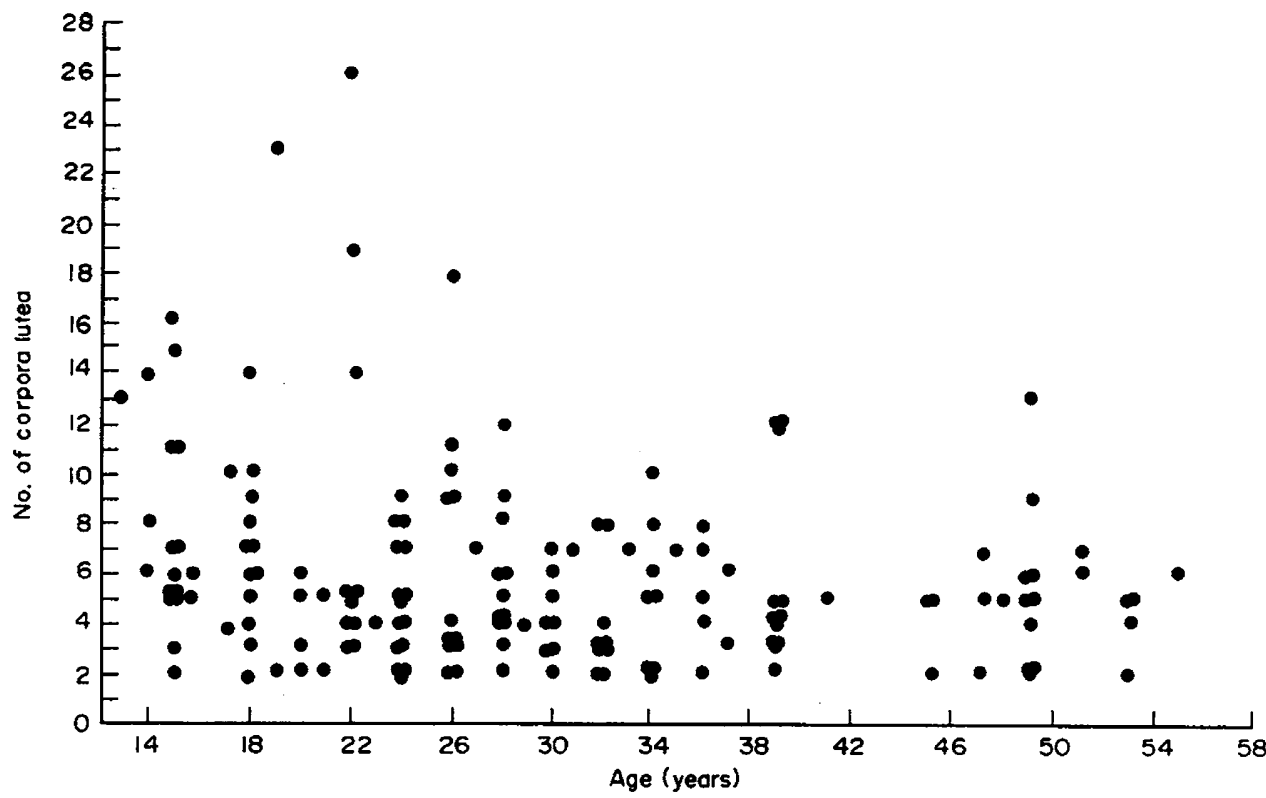

TEXT-FIG. 3. Number of $\mathrm{CL}$ in pregnant elephants in relation to their age. 
older animals $(P<0 \cdot 05)$. The size of the GL in pregnant and non-pregnant animals also varied significantly with age, the older animals having more cL with a diameter in excess of $20 \mathrm{~mm}$ (see Text-fig. 4).

There was no indication that more ovulations occurred in the left ovary than

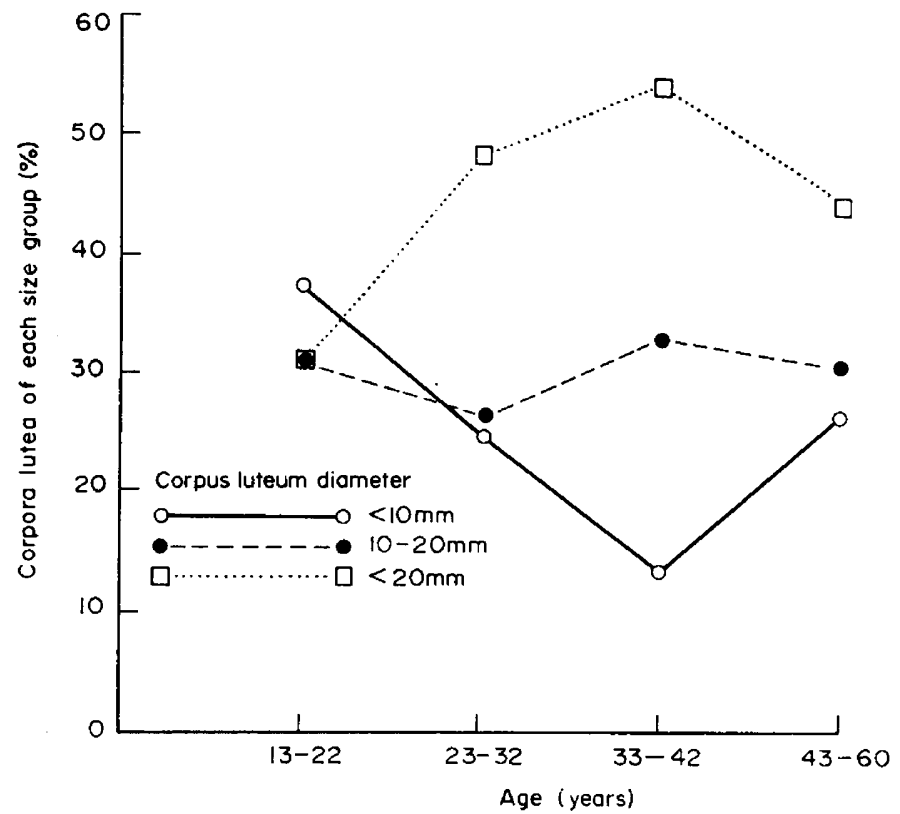

TEXT-FIG. 4. Diameter of the CL in pregnant and non-pregnant elephants combined in relation to their age.

\section{EXPLANATION OF PLATES}

\section{PLATE 1}

Macroscopic appearance of the uterus in relation to reproductive status. Elephant number refers to animals in Text-fig. 1 .

FIG. 1. Elephant No. 10-not pregnant ( $3.2 \mathrm{~g}$ luteal tissue). Uterus has typical appearance of the prepubertal elephant.

FrG. 2. Elephant No. 13-not pregnant $(12.8 \mathrm{~g}$ luteal tissue). One very recent ovulation. Enlarged hyperaemic uterus.

Fig. 3. Pregnant (49.1 g luteal tissue) with 2-month-old fetus. Lumen of uterus completely occluded.

FIG. 4. Pregnant (25.4 g luteal tissue) with 5-month-old fetus. Relaxation of uterine tone, and reappearance of lumen.

\section{PLATE 2}

Endometrial histology in relation to reproductive status. Elephant number refers to animals in Text-fig. $1 . \times 90$.

Fig. 1. Elephant No. 2-prepubertal. Small endometrial glands with low density near the myometrium.

FIG. 2. Elephant No. 6-lactational anoestrus. Similar to the prepubertal elephant.

Fig. 3. Elephant No. 16-not pregnant (22.6 g luteal tissue). Well developed epithelium, enlarged endometrial glands and increased density near the myometrium.

Fig. 4. Elephant No. 15-not pregnant ( $31.5 \mathrm{~g}$ luteal tissue). Similar to No. 16, with well-developed endometrial crypts. 
PLAL1

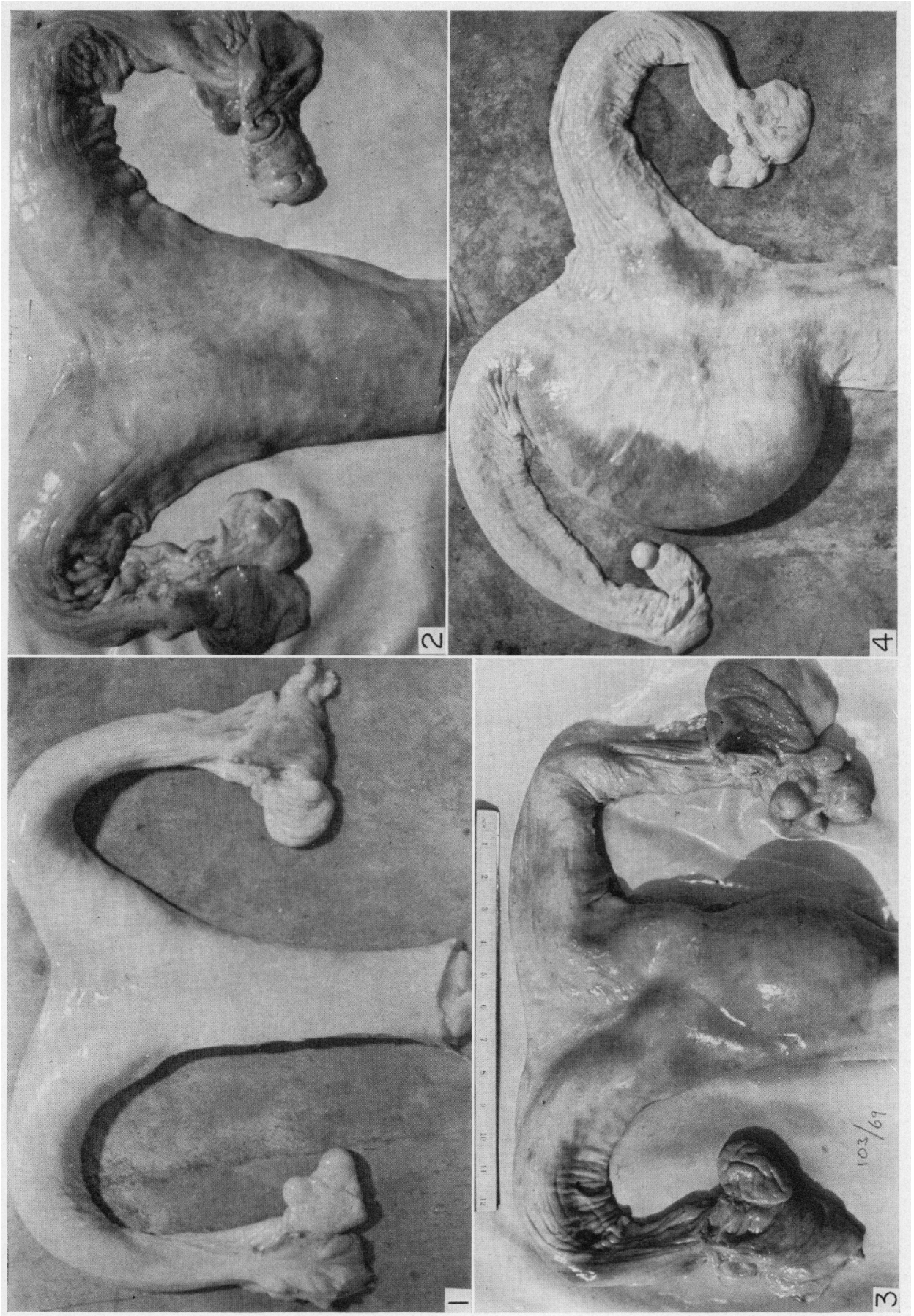

(Facing p. 84) 


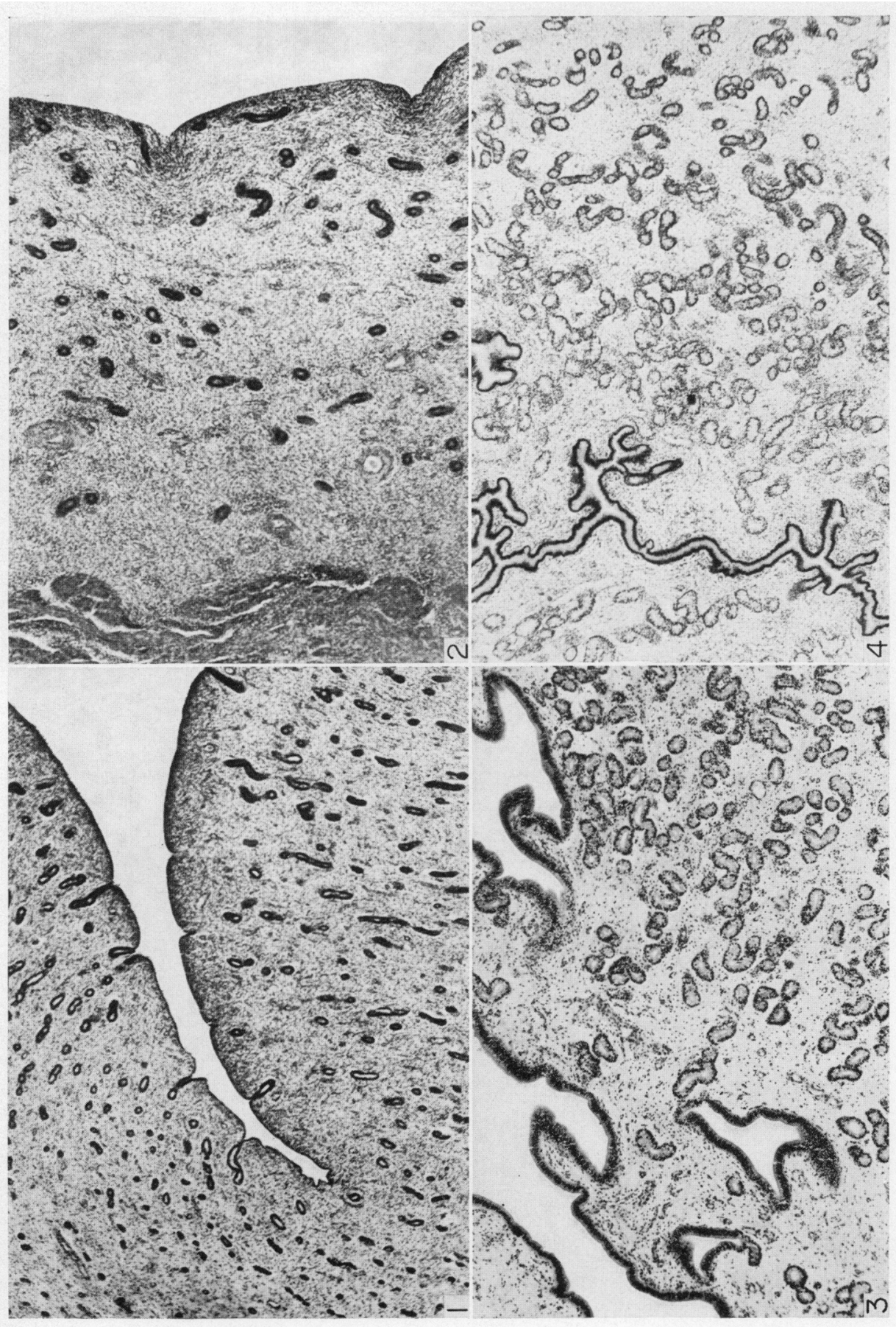




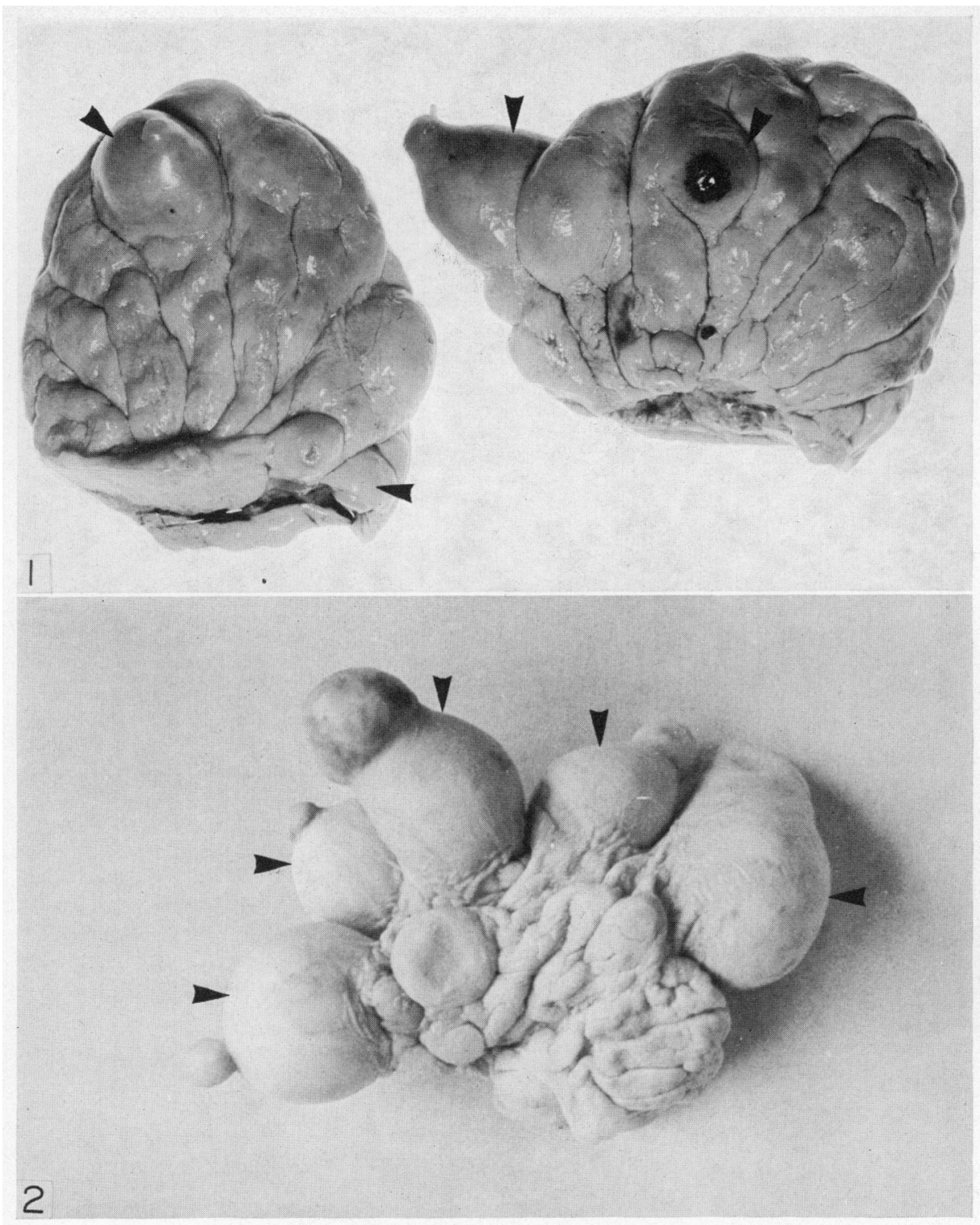

Corpora lutea in pregnant and non-pregnant elephants, showing the disparity in size and number. Arrows point to the CL.

FIG. 1. Reproduced from Short (1966). Three small CL and a single fresh ovulation point from a non-pregnant elephant just after the end of oestrus ( $9.5 \mathrm{~g}$ luteal tissue).

Fig. 2. Five large cL in the left ovary of a 2-week pregnant elephant. The right ovary had no $\mathrm{CL}(89.9 \mathrm{~g}$ luteal tissue). 


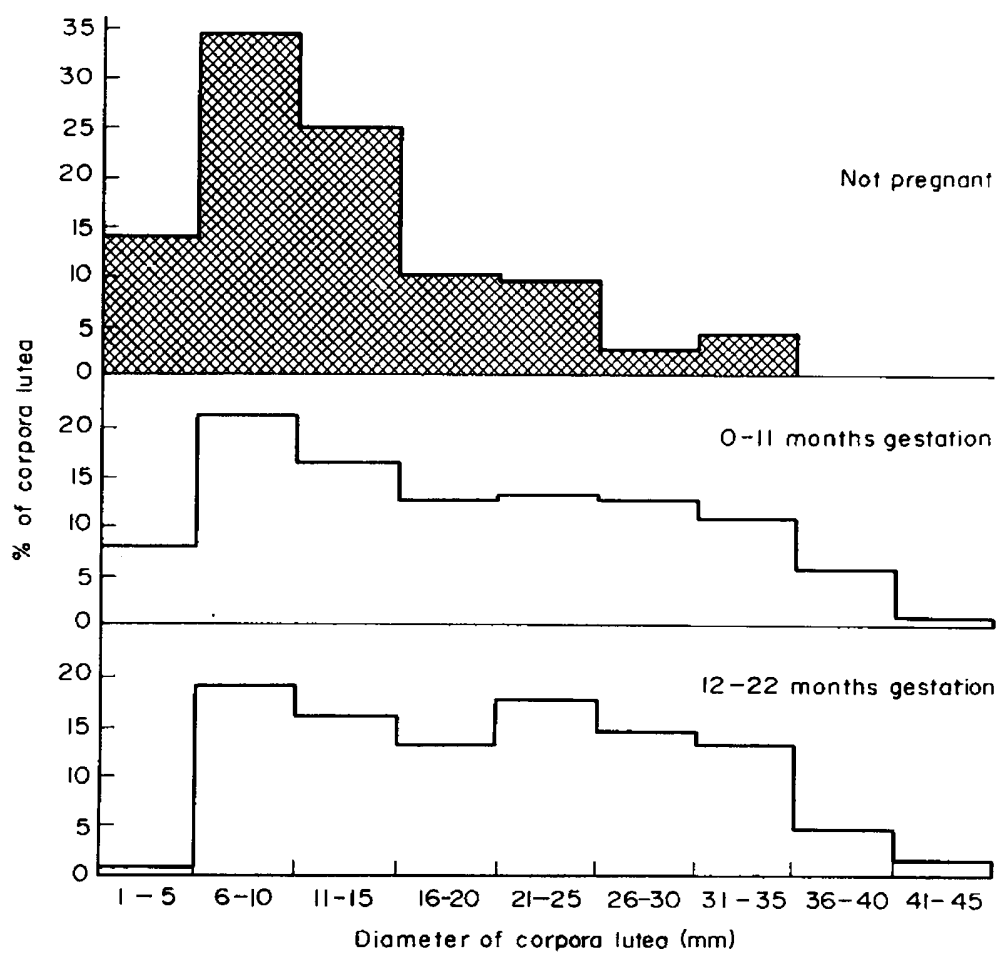

TExT-FIG. 5. Diameter of the cL in non-pregnant elephants (solid histogram) compared with pregnant elephants in the two halves of gestation (open histogram).

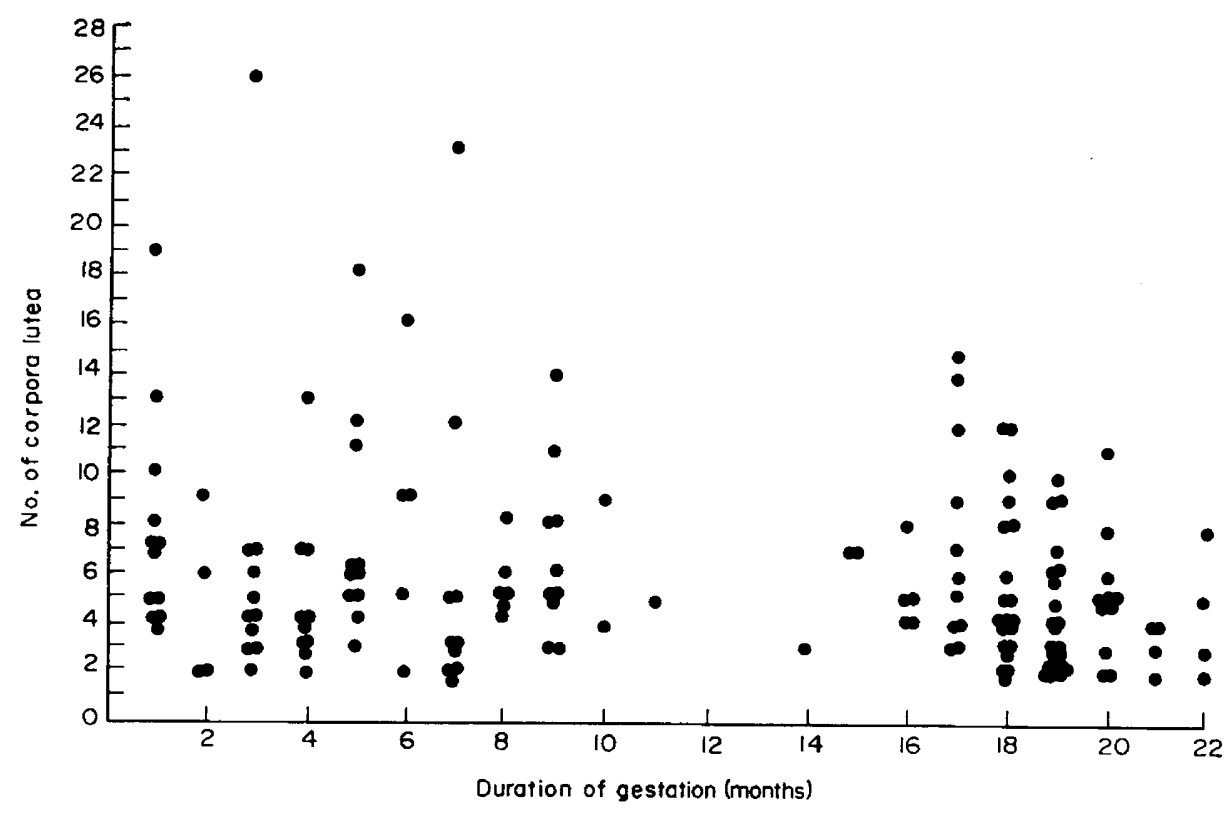

Text-rig. 6. Number of $\mathrm{cL}$ in relation to the stage of gestation in the African elephant. 
in the right. Twenty-two pregnant elephants had cL in only one ovary, and in every case the embryo was on the same side as the CL, suggesting that transuterine migration is an uncommon event.

In non-pregnant elephants, $14 \%$ of the CL were very small $(<6 \mathrm{~mm}$ in diameter); in the first half of gestation, this figure had fallen to $8 \%$ and by the second half of gestation, to only $1 \%$ (see Text-fig. 5); this decline was statistically significant $(P<0.05)$, and histologically it was possible to identify regressing small $\mathrm{CL}$

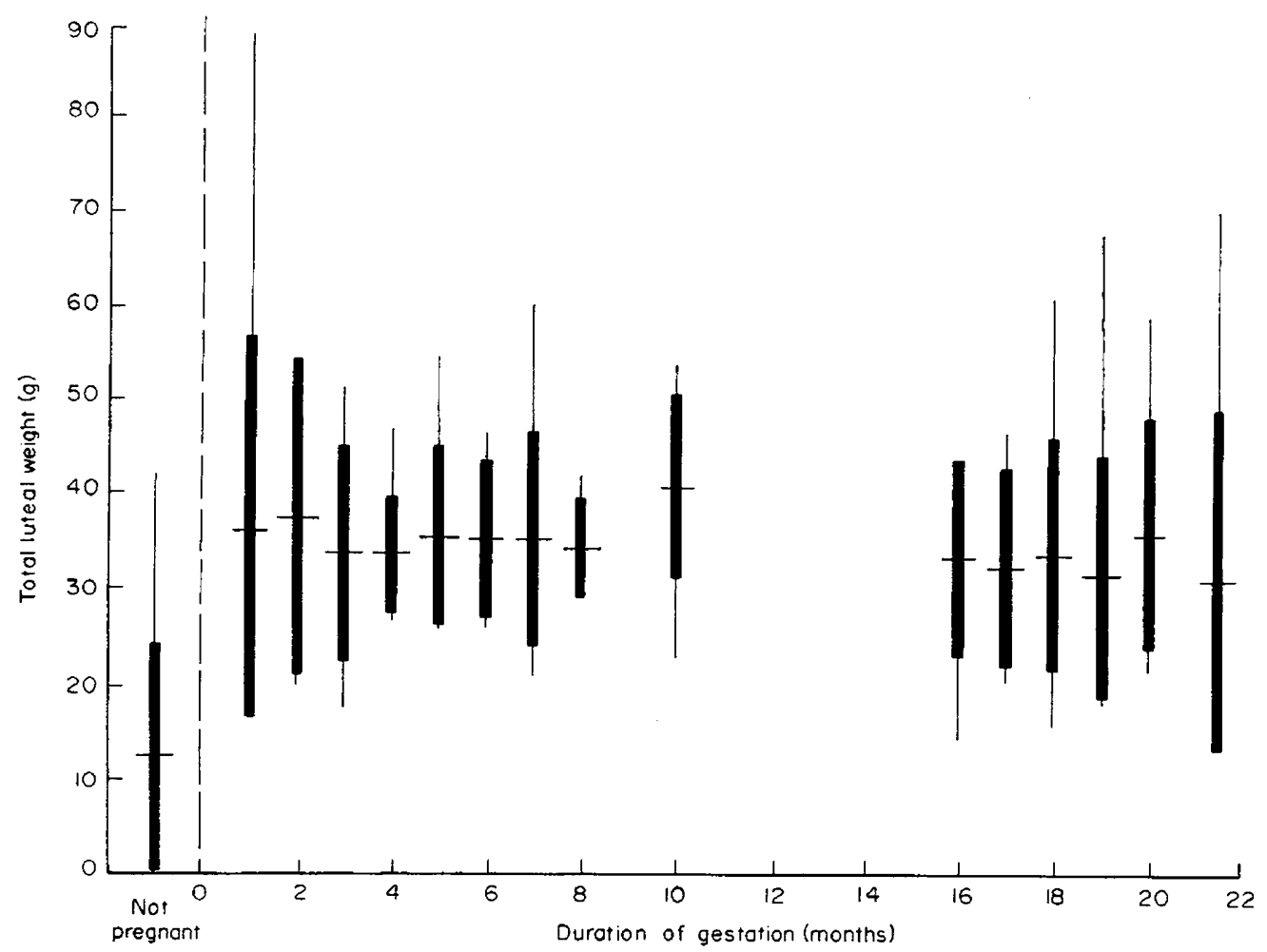

TEXT-FIG. 7. Variations in total luteal tissue weight in non-pregnant elephants compared with those at various stages of gestation (range, mean and standard deviation).

throughout pregnancy in some animals. The larger aL did not suffer the same fate, and appeared to persist unaltered throughout the whole course of gestation. Thus, although there was a significant $(P<0.05)$ decline in the number of CL in the second half of gestation (see Text-fig. 6), this was not reflected in a significant decline in luteal weight (see Text-fig. 7).

There was a highly significant difference $(P<0.001)$ between pregnant and non-pregnant elephants in the total weight of the luteal tissue; all animals in the first half of gestation had more than $17.3 \mathrm{~g}$ luteal tissue, whereas $68 \%$ of nonpregnant animals had less than this amount. Since there was no indication of hypertrophy of CL once an animal had become pregnant, the greater weight of the luteal tissue in pregnant animals is probably a reflection of the fact that it is necessary to accumulate a critical mass of luteal tissue before an animal can conceive. 
The most conclusive evidence that replacement of cL does not occur during pregnancy was obtained from five primiparous animals in the second half of gestation. None of these had a single corpus albicans in their ovaries, showing that no luteal regression had occurred since puberty.

It is clearly impossible to draw any conclusions about the functional activity of GL just by looking at their structure. Although endometrial histology suggests that the corpora lutea are functional, we were unable to detect any progesterone $(<0.2 \mathrm{ng} / \mathrm{ml}$ plasma) in the peripheral blood of four elephants at various stages of pregnancy and, understandably, there was also none present in an animal in lactational anoestrus (see Table 3).

TABLE 3

PERIPHERAL BLOOD PROGESTERONE LEVELS IN ELEPHANTS

\begin{tabular}{|c|c|c|c|c|c|}
\hline $\begin{array}{c}\text { Animal } \\
\text { no. }\end{array}$ & $\begin{array}{c}\text { Age } \\
\text { (years) }\end{array}$ & Reproductive status & $\begin{array}{l}\text { No. } \\
\text { of } C L\end{array}$ & $\begin{array}{l}\text { Total weight of } \\
\text { luteal tissue } \\
(\mathrm{g})\end{array}$ & $\begin{array}{c}\text { Progesterone } \\
(\mathrm{ng} / \mathrm{ml} \text { plasma })\end{array}$ \\
\hline 1 & 53 & $\begin{array}{l}\text { Not pregnant; } \\
\text { lactational anoestrus }\end{array}$ & 0 & 0 & $<0.1$ \\
\hline 2 & 15 & $\begin{array}{l}1 \text { month pregnant; } \\
2 \cdot 0-g \text { embryo; } \\
\text { first pregnancy }\end{array}$ & 7 & $49 \cdot 2$ & $<0.1$ \\
\hline 3 & 47 & $\begin{array}{l}20 \text { months pregnant; } \\
96.5-\mathrm{kg} \text { fetus }\end{array}$ & 2 & $37 \cdot 2$ & $<0.2$ \\
\hline 4 & 15 & $\begin{array}{l}20 \text { months pregnant; } \\
83.5-\mathrm{kg} \text { fetus; } \\
\text { first pregnancy }\end{array}$ & 6 & $54 \cdot 6$ & $<0.2$ \\
\hline 5 & 32 & $\begin{array}{l}22 \text { months pregnant; } \\
\text { near term; } \\
122 \cdot 5 \text {-kg fetus }\end{array}$ & 2 & $23 \cdot 6$ & $<0.1$ \\
\hline
\end{tabular}

\section{DISGUSSION}

It is difficult to explain why the elephant should show so much variability in the number and size of its CL. Contrary to the view expressed by Perry (1953), it now seems certain that new CL are not formed during pregnancy (Buss \& Smith, 1966; Laws, 1969, and the present observations). Thus, the number of CL found during pregnancy provides a minimal estimate of the number that must have been present at conception. If the elephant is monovular, but has a number of oestrous cycles (Short, 1966), accumulating CL until it eventually becomes pregnant, this would mean that some animals would have over twenty cycles before conceiving. Although the length of the oestrous cycle in the African elephant is not known, the Asiatic elephant has a cycle of about 3 weeks duration (Jainudeen, Eisenberg \& Tilakeratne, 1971). Assuming that the African elephant is similar, this would mean that some animals must cycle for well over a year before conceiving. The relative paucity of non-pregnant cycling animals in our cropped sample taken from a population where a calf is born every 4 years (Hanks, 1972), suggests that this cannot normally be the case, although single ovulations do sometimes occur.

Another possibility would be that the elephant is polyovular and conceives at 
the first oestrus. Once again, this may sometimes be true but we have definite evidence on three occasions of fresh ovulations occurring in the presence of an existing set of cL. Furthermore, the fact that non-pregnant elephants had less luteal tissue than pregnant ones suggests that successive crops of CL do accumulate before an animal eventually becomes pregnant.

The most probable explanation is that the elephant is usually polyovular, and may undergo a number of oestrous cycles before conceiving; unlike other mammals, the cL persist from one cycle to the next.

In the non-pregnant elephant, the cL probably do not last for more than a few months; Diksie, an unmated, 27-year-old elephant that died in the London Zoo, only had three CL in her ovaries, but she had far more corpora albicantia than normal for an animal of this age (Short, 1969). In addition, a 15-year-old elephant was shot in Zambia that had never been pregnant; although it had no CL there were six corpora albicantia. During pregnancy, there seems to be a luteotrophic stimulus, since all the large cL present at conception persist for the 22 months of gestation, and regress about 2 months after parturition (Buss \& Smith, 1966; Laws, 1969).

The variability in luteal size cannot be entirely explained by luteinization of unruptured follicles, because both large and small cL showed ovulation stigmata. Non-pregnant animals had a high incidence of very small CL, and a paucity of large ones. Since every pregnant animal had at least one large cL, it is almost as if this is a necessary prerequisite for conception. Once an animal has become pregnant, a number of the small cL begin to regress.

The most baffling feature of the elephant's CL is its relative inability to secrete progesterone. Although we have isolated very small amounts of progesterone from a large pool of elephant CL, and shown that the enzyme systems necessary for the conversion of pregnenolone to progesterone are present (Smith et al., 1969), in this study we completely failed to detect any progesterone in the peripheral blood at various stages of pregnancy. Corpora lutea do seem to be necessary for endometrial development, and if progesterone is the hormone responsible, then the elephant must be extremely sensitive to it. The relative inactivity of the CL may be the reason for the necessity to accumulate a large mass of luteal tissue from successive ovulations before conception is possible.

\section{ACKNOWLEDGMENTS}

The assistance and co-operation of Dr P. Albl, Mr J. Botha and Mr R. Langeveld at the Kakumbi Abattoir are gratefully acknowledged. Mr A. A. Phiri assisted with the histological preparations and Mrs. J. Fraser carried out the progesterone determinations. The UN/FAO Luangwa Valley Conservation and Development Project provided facilities at Kakumbi and Chipata, and the World Wildlife Fund financed one of us (J.H.) for the completion of this study in Cambridge.

\section{REFERENCES}

Buss, I. O. \& SмтTH, N. S. (1966) Observations on reproduction and breeding behaviour of the African elephant. F. Wildl. Mgmt, 30, 375. 
Department of Wildlife, Fisheries and National Parks (1969) Annual Report. Government Printer, Lusaka.

HANKs, J. (1972) Reproduction of elephant, Loxodonta africana, in the Luangwa Valley, Zambia. $\mathcal{F}$. Reprod. Fert. 30 (In press).

Jainudeen, M. R., Eisenberg, J. F. \& Tilakeratne, N. (1971) Oestrous cycle of the Asiatic elephant, Elephas maximus, in captivity. J. Reprod. Fert. 27, 329.

LAws, R. M. (1966) Age criteria for the African elephant, Loxodonta a. africana. E. Afr. Wildl. Fnl, 4, 1.

LAws, R. M. (1969) Aspects of reproduction in the African elephant, Loxodonta africana. F. Reprod. Fert., Suppl. 6, 193.

PERry, J. S. (1953) The reproduction of the African elephant, Loxodonta africana. Phil. Trans. R. Soc. B, 237, 93.

Schomberg, D. W., Coudert, S. P. \& Short, R. V. (1967) Effects of bovine luteinizing hormone and human chorionic gonadotrophin on the bovine corpus luteum in vivo. F. Reprod. Fert. 14, 277.

SHORT, R. V. (1966) Oestrous behaviour, ovulation and the formation of the corpus luteum in the African elephant, Loxodonta africana. E. Afr. Wildl. Fnl, 4, 56.

SHORT, R. V. (1969) Notes on the teeth and ovaries of an African elephant (Loxodonta africana) of known age. F. Zool., Lond. 158, 421.

SHoRt, R. V. \& Buss, I. O. (1965) Biochemical and histological observations on the corpora lutea of the African elephant, Loxodonta africana. 7. Reprod. Fert. 9, 61.

Sмith, J. G., Hanks, J. \& Short, R. V. (1969) Biochemical observations on the corpora lutea of the African elephant, Loxodonta africana. F. Reprod. Fert. 20, 111. 